\title{
Characteristics of Blended Geopolymer Concrete Using Ultrafine Ground Granulated Blast Furnace Slag and Copper Slag
}

\author{
Vijayasarathy Rathanasalam*, Jayabalan Perumalsami, Karthikeyan Jayakumar \\ Department of Civil Engineering, National Institute of Technology, Trichy 620015, Tamil Nadu, India
}

Corresponding Author Email: vijayasarathy.civil@gmail.com

https://doi.org/10.18280/acsm.440610

Received: 6 July 2020

Accepted: 24 November 2020

\section{Keywords:}

geopolymer concrete, copper slag, fly ash, ultrafine ground granulated blast furnace slag

\begin{abstract}
This paper presents the properties of blended geopolymer concrete manufactured using fly ash and ultrafine Ground Granulated Blast Furnace Slag (UFGGBFS), along with the copper slag (CPS) as replacement of fine aggregate (crushed stone sand). Various parameters considered in this study include different sodium hydroxide concentrations (10M, $12 \mathrm{M}$ and $14 \mathrm{M}) ; 0.35$ as alkaline liquid to binder ratio; 2.5 as sodium silicate to sodium hydroxide ratio and cured in ambient curing condition. Further, geopolymer concrete was manufactured using fly ash as the prime source material which is replaced with UFGGBFS $(0 \%, 5 \%, 10 \%$ and $15 \%)$. Copper slag has been used as replacement of fine aggregate in this study. Properties of the fresh manufactured geopolymer concrete were studied by slump test. Compressive strength of the manufactured geopolymer concrete was tested and recorded after curing for 3, 7 and 28 days. Microstructure Characterization of Geopolymer concrete specimens was done by Scanning Electron Microscope (SEM) analysis. Experimental results revealed that the addition of UFGGBFS resulted in an increased strength performance of geopolymer concrete. Also, this study demonstrated that the strength of geopolymer concrete increased with an increase in sodium hydroxide concentration. SEM results revealed that the addition of UFGGBFS resulted in a dense structure.
\end{abstract}

\section{INTRODUCTION}

Concrete is the second largest used material in the world, next to water [1]. Each material used to make concrete increases the concern for durability [2]. Portland Cement is the main ingredient to make concrete. The manufacture of OPC releases approximately $5 \%$ to $7 \%$ of the total greenhouse gases (mainly $\mathrm{CO}_{2}$ ) into the atmosphere [3]. In addition, the demand for concrete is increasing every day. With regard to sustainability and increasing demand, the search for an alternative binding material is necessary. One such alternate to conventional concrete is geopolymer concrete which is manufactured by the alkali activation of aluminosilicate materials. Geopolymer is obtained from the polymerization of aluminosilicate rich source materials/by-product materials by an activator solution (alkaline). The most commonly used alkaline activator solution is a blend of sodium silicate solution $\left(\mathrm{Na}_{2} \mathrm{SiO}_{3}\right)$ and sodium hydroxide solution $(\mathrm{NaOH})$ or potassium silicate solution $\left(\mathrm{K}_{2} \mathrm{SiO}_{3}\right)$ and potassium hydroxide solution (KOH). An extensive variety of industrial byproducts like fly ash [4, 5]; ground granulated blast furnace slag [6]; rice husk ash [7, 8], red mud [8], metakaolin [9], etc. can be used as raw materials that have reactive silica and alumina.

Jawahar et al. [10] stated that geopolymer concrete made with fly ash as the prime source material showed poor results when cured in ambient temperature. Studies by various researchers [11, 12] stated that the addition of GGBFS enabled ambient curing of geopolymer concrete along with strength and stability. The conventional use of natural river sand as a fine aggregate to manufacture concrete is very high and constant increase in its demand due to infrastructure developments results in decreased availability of natural river sand in the near future. To overcome this problem, an alternative fine aggregate is essential. Researchers throughout the world have studied the use of slag [13], quarry dust [14], granite fines [15-18], copper slag [19, 20], etc. as replacement of conventionally used natural sand as fine aggregate for the manufacture of concrete. Studies by Mahendran and Arunachalam [21] on GPC manufactured using copper slag as fine aggregate showed better results in terms of compressive strength. Studies by Neethu Susan [22] revealed that limited replacement of copper slag in GPC affects the mechanical strength as well as durability properties. Further, they stated that the addition of up to $40 \%$ copper slag as partial replacement of natural sand to GPC showed better results as compared to that of GPC manufactured only with natural sand as fine aggregate.

At present, several studies have been carried out on the performance of copper slag as an alternative to natural sand as fine aggregate in the manufacture of conventionally used Portland cement-based concrete, but there are limited studies on the behaviour of copper slag as an alternative to natural sand or crushed stone sand as fine aggregate in the manufacture of GPC and its strength performance, etc.

Based on the understanding of literatures, the present investigation is focused on the manufacture of ambient cured Geopolymer Concrete (GPC) using fly ash and ultrafine ground granulated blast furnace slag as the aluminosilicate source materials along with copper slag as a replacement of 
fine aggregate. Use of copper slag as fine aggregate will pave way to manufacture a more sustainable and environmentally friendly geopolymer concrete. Further, Sodium hydroxide and Sodium Silicate combinedly have been considered as the alkaline activator solution. Three numbers of geopolymer concrete specimens for each mix is considered for this study and their average is taken to understand the behaviour of geopolymer concrete.

\section{EXPERIMENTAL STUDY}

\subsection{Materials used}

In this study, class F Fly ash with a specific gravity of 2.64 procured from Mettur Thermal Power Plant, INDIA and confirming to IS 3812 (1) - 2013 [23] has been used as the prime source material. The chemical composition of class $\mathrm{F}$ fly ash used is given in Table 1. Ultrafine ground granulated blast furnace slag (UFGGBFS) having material size between 4 to 6 microns, specific surface area $12,000 \mathrm{~cm}^{2} / \mathrm{gm}$, specific gravity of 2.72 has been used. The chemical composition of UFGGBFS is given in Table 1. Well-graded aggregate of size $12.5 \mathrm{~mm}$ with a specific gravity of 2.83 and confirming to IS 383-1970 [24] has been used as coarse aggregate. Copper slag, a black colored glassy granular particle as per IS: 2386 (Part
I)-1963 [25] with a specific gravity of 3.50 has been used to replace fine aggregate in this study. The chemical composition of copper slag used in presented in Table 1. Naphthalene sulfonate-based superplasticizer has been used to improve workability as per IS 9130: 1999 [26].

A combination of sodium silicate solution and sodium hydroxide solution in the ratio of 2.5 has been used as alkaline activator. Commercial grade $\mathrm{NaOH}$ in pellet form and liquid $\mathrm{Na}_{2} \mathrm{SiO}_{3}\left(\mathrm{Na}_{2} \mathrm{O}=16.38 \%, \mathrm{SiO}_{2}=37.02\right.$, water $\left.=46.59\right)$ has been used.

\subsection{Preparation of geopolymer concrete specimen}

$\mathrm{NaOH}$ solution has been prepared for 10M (314 grams of $\mathrm{NaOH} / 1$ lit of $\mathrm{NaOH}$ solution), 12M (361 grams of $\mathrm{NaOH} /$ 1 lit of $\mathrm{NaOH}$ solution) and 14M (404 grams of $\mathrm{NaOH} / 1$ lit of $\mathrm{NaOH}$ Solution) concentrations. Preparation of $\mathrm{NaOH}$ was done at room temperature and kept to cool at room temperature. After 24 hours, $\mathrm{Na}_{2} \mathrm{SiO}_{3}$ was mixed along with the $\mathrm{NaOH}$ solution in the ratio of 2.5. All the geopolymer constituent materials were dry mixed in the laboratory before they were mixed with the alkaline liquid (along with superplasticizer). Mixed Geopolymer concrete specimens were being cast in cube specimen of size $150 \mathrm{~mm} \times 150 \mathrm{~mm} \times 150 \mathrm{~mm}$ to determine the compressive strength after 3 days, 7 days and 28 days of curing.

Table 1. Chemical composition of Class F fly ash, UFGGBFS and Copper slag

\begin{tabular}{cccccccccc}
\hline \multirow{2}{*}{ Material } & \multicolumn{8}{c}{ Chemical composition (w/w) } \\
\cline { 2 - 11 } & $\mathrm{SiO}_{2}$ & $\mathrm{Al}_{2} \mathbf{O}_{3}$ & $\mathrm{Fe}_{2} \mathrm{O}_{3}$ & $\mathbf{S O}_{3}$ & $\mathbf{C a O}$ & $\mathrm{Na}_{2} \mathrm{O}$ & $\mathbf{K}_{2} \mathbf{O}$ & $\mathbf{M g O}$ & $\mathbf{L O I}$ \\
\hline Class F Fly ash & 61.30 & 26.62 & 4.55 & 0.28 & 1.20 & 0.22 & 1.32 & 0.50 & 0.55 \\
UFGGBFS & 33.00 & 22.40 & 1.70 & - & 34.20 & - & - & 6.00 & - \\
Copper Slag & 31.20 & 2.42 & 55.00 & 1.92 & 5.37 & 0.25 & 0.66 & 1.54 & - \\
\hline
\end{tabular}

Table 2. Mixture proportioning of geopolymer concrete using UFGGBFS and Copper Slag

\begin{tabular}{|c|c|c|c|c|c|c|c|c|}
\hline \multirow{2}{*}{$\begin{array}{c}\text { Mix } \\
\text { Designation }\end{array}$} & \multirow{2}{*}{$\begin{array}{c}\mathrm{NaOH} \\
\text { concentration }\end{array}$} & \multirow[b]{2}{*}{$\begin{array}{l}\text { Fly ash } \\
\left(\mathrm{kg} / \mathrm{m}^{3}\right)\end{array}$} & \multirow[b]{2}{*}{$\begin{array}{l}\text { UFGGBFS } \\
\left(\mathbf{k g} / \mathbf{m}^{3}\right)\end{array}$} & \multirow[b]{2}{*}{$\begin{array}{c}\text { Coarse aggregate } \\
\left(\mathrm{kg} / \mathrm{m}^{3}\right)\end{array}$} & \multicolumn{2}{|c|}{ Fine aggregate } & \multicolumn{2}{|c|}{ Alkaline activator solution } \\
\hline & & & & & $\begin{array}{c}\text { Crushed stone } \\
\text { sand }\left(\mathrm{kg} / \mathrm{m}^{3}\right)\end{array}$ & $\begin{array}{c}\text { Copper Slag } \\
\left(\mathrm{kg} / \mathrm{m}^{3}\right)\end{array}$ & $\begin{array}{c}\mathrm{NaOH} \\
\left(\mathrm{kg} / \mathrm{m}^{3}\right)\end{array}$ & $\begin{array}{c}\mathrm{Na}_{2} \mathrm{SiO}_{3} \\
\left(\mathrm{~kg} / \mathrm{m}^{3}\right)\end{array}$ \\
\hline M11 & \multirow{8}{*}{$10 \mathrm{M}$} & 408 & 0 & \multirow{4}{*}{1257} & 592 & 0 & 42 & 105 \\
\hline M12 & & 388 & 20 & & 592 & 0 & 42 & 105 \\
\hline M13 & & 367 & 41 & & 592 & 0 & 42 & 105 \\
\hline M14 & & 347 & 61 & & 592 & 0 & 42 & 105 \\
\hline M21 & & 408 & 0 & \multirow{4}{*}{1257} & 0 & 592 & 42 & 105 \\
\hline M22 & & 388 & 20 & & 0 & 592 & 42 & 105 \\
\hline M23 & & 367 & 41 & & 0 & 592 & 42 & 105 \\
\hline M24 & & 347 & 61 & & 0 & 592 & 42 & 105 \\
\hline M11 & \multirow{8}{*}{$12 \mathrm{M}$} & 408 & 0 & \multirow{4}{*}{1257} & 592 & 0 & 42 & 105 \\
\hline M12 & & 388 & 20 & & 592 & 0 & 42 & 105 \\
\hline M13 & & 367 & 41 & & 592 & 0 & 42 & 105 \\
\hline M14 & & 347 & 61 & & 592 & 0 & 42 & 105 \\
\hline M21 & & 408 & 0 & \multirow{4}{*}{1257} & 0 & 592 & 42 & 105 \\
\hline M22 & & 388 & 20 & & 0 & 592 & 42 & 105 \\
\hline M23 & & 367 & 41 & & 0 & 592 & 42 & 105 \\
\hline M24 & & 347 & 61 & & 0 & 592 & 42 & 105 \\
\hline M11 & \multirow{8}{*}{$14 \mathrm{M}$} & 408 & 0 & \multirow{4}{*}{1257} & 592 & 0 & 42 & 105 \\
\hline M12 & & 388 & 20 & & 592 & 0 & 42 & 105 \\
\hline M13 & & 367 & 41 & & 592 & 0 & 42 & 105 \\
\hline M14 & & 347 & 61 & & 592 & 0 & 42 & 105 \\
\hline M21 & & 408 & 0 & \multirow{4}{*}{1257} & 0 & 592 & 42 & 105 \\
\hline M22 & & 388 & 20 & & 0 & 592 & 42 & 105 \\
\hline M23 & & 367 & 41 & & 0 & 592 & 42 & 105 \\
\hline M24 & & 347 & 61 & & 0 & 592 & 42 & 105 \\
\hline
\end{tabular}

Curing of geopolymer concrete specimens has been done by two ways. In the first case, where Fly ash has been used alone as a binder, curing in an oven at $60^{\circ}$ has been adopted [27]. In the second case, where fly ash has been replaced by $5 \%, 10 \%$ 
and $15 \%$ UFGGBFS, ambient temperature curing of geopolymer concrete specimens has been adopted. Then, the specimens were cured and kept in the laboratory until the time of testing. The mix proportioning of geopolymer concrete is given in Table 2. Overall, mix designations M11, M12, M13 and M14 represent geopolymer concrete mix with $100 \%$ crushed stone sand as the fine aggregate and Mix designations M21, M22, M23 and M24 represent geopolymer concrete mix having $100 \%$ copper slag used as replacement of crushed stone sand. Further, the mix designation M11 and M21 represent the geopolymer mix with $100 \%$ fly ash as the binding material; M12 and M22 represent the geopolymer mix with 95\% fly ash as the binding material along with 5\% UFGGBFS; M13 and M23 represent the geopolymer mix with $90 \%$ fly ash as the binding material along with 10\% UFGGBFS; and M14 and M24 represent the geopolymer mix with $85 \%$ fly ash as the binding material along with $15 \%$ UFGGBFS.

\subsection{Testing}

Slump test [28] has been used to determine the workability of geopolymer concrete in a fresh state. Compressive strength of geopolymer concrete specimens has been performed on cube specimens having size of $150 \mathrm{~mm} \times 150 \mathrm{~mm} \times 150 \mathrm{~mm}$ per mix according to IS: 516-1959 [29]. The reported values represent an average of measurement on three cube specimens.

\section{RESULTS AND DISCUSSION}

\subsection{Properties of geopolymer concrete in fresh state}

The workability of fresh geopolymer concrete has been determined by slump test and the corresponding experimental results are plotted graphically in Figure 1.

From Figure 1, it is to be seen that the workability of fresh geopolymer concrete decreases with increase in $\mathrm{NaOH}$ concentration. It can be inferred from Figure 1 (a) that for Mix M14 having 15\% UFGGBFS as replacement of fly ash content, the slump decreases by $16.35 \%$ from $110 \mathrm{~mm}(10 \mathrm{M} \mathrm{NaOH}$ concentration) to $92 \mathrm{~mm}$ (14M NaOH concentration). A similar tendency of decreased workability in fresh state with an increase in $\mathrm{NaOH}$ concentration is seen for geopolymer concrete manufactured using copper slag as fine aggregate. The reason behind this decrease may be the high viscous nature of alkaline activator solution used to manufacture geopolymer concrete. Further, from Figure 1 (a) and Figure 1 (b), it is clear that adding UFGGBFS to geopolymer concrete as limited replacement of fly ash increases the slump value. For instance, from Figure 1 (b) it is to be seen that addition of $15 \%$ UFGGBFS to geopolymer concrete having $12 \mathrm{M} \mathrm{NaOH}$ concentration increases the slump value by $28.95 \%$ from $114 \mathrm{~mm}(100 \%$ fly ash - mix M21) to $147 \mathrm{~mm}(15 \%$ UFGGBFS - mix M24). This may be attributed to the reason that UFGGBFS acts as a filler material thus increasing workability [30]. Also, it is evident from Figure 1 (a) and Figure 1 (b) that the replacement of crushed stone sand by using copper slag as fine aggregate enhances the workability of geopolymer concrete in fresh state. For instance, for geopolymer concrete with $10 \%$ UFGGBFS as replacement of fly ash having $14 \mathrm{M} \mathrm{NaOH}$ concentrations, the slump increases by $18.18 \%$ from $110 \mathrm{~mm}$ (mix M13) to $130 \mathrm{~mm}$ (mix M23). This increase in workability with the addition of copper slag as replacement of fine aggregate may be credited to the low water absorption characteristics of copper slag [31].

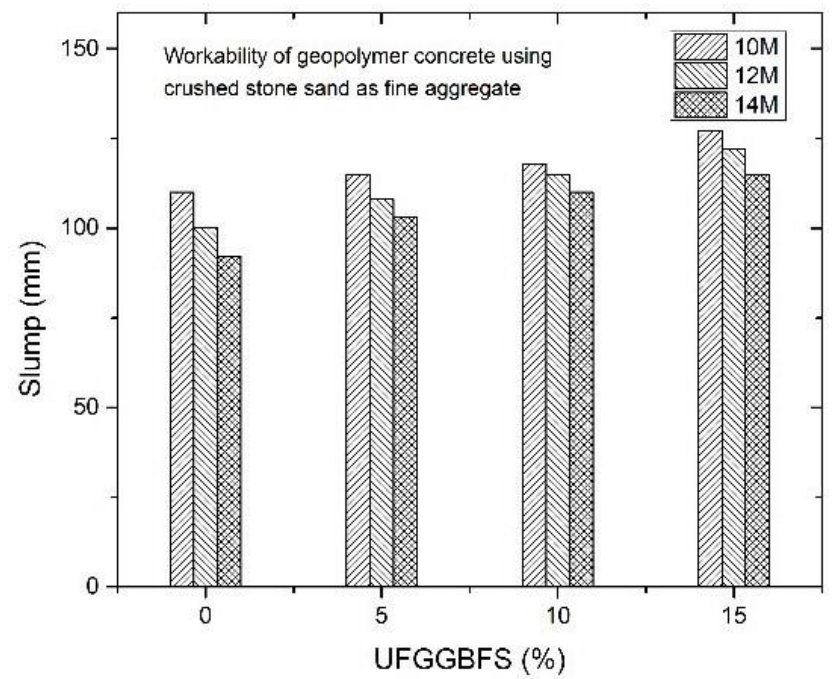

(a)

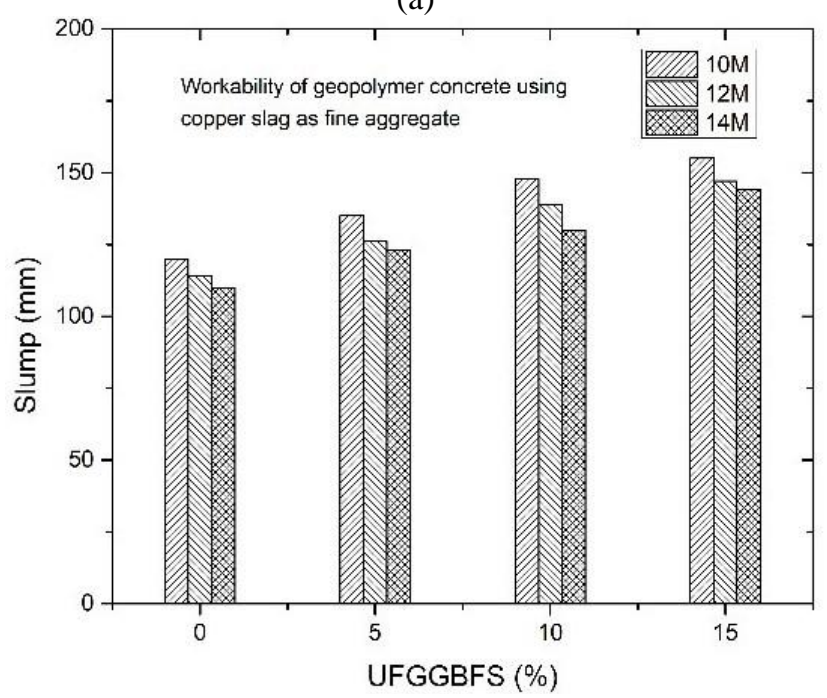

(b)

Figure 1. Workability of geopolymer concrete using (a) crushed stone sand as fine aggregate (b) copper slag as fine aggregate

\subsection{Properties of geopolymer concrete in hardened state}

Properties of geopolymer concrete in hardened state has been done to assess the compressive strength of cube specimens having a size $150 \mathrm{~mm} \times 150 \mathrm{~mm} \times 150 \mathrm{~mm}$. The cast, cured geopolymer concrete cube specimens were tested for compressive strength at 3 days, 7 days and 28 days of curing and its corresponding results have been plotted graphically. Figure 2 (a) illustrates the compressive strength of geopolymer concrete manufactured using crushed stone sand as fine aggregate after 3 days of curing and Figure 2 (b) shows the compressive strength of geopolymer concrete manufactured using copper slag as fine aggregate after 3 days of curing.

From Figure 2, it is inferred that the compressive strength of geopolymer concrete increases with increase in $\mathrm{NaOH}$ concentration. It can also be inferred from Figure 2 (a) that the 3-day compressive strength of geopolymer concrete mix M14 having $15 \%$ UFGGBFS content as replacement of fly ash and crushed stone sand as fine aggregate increases by $22.01 \%$ from $26.67 \mathrm{~N} / \mathrm{mm}^{2}$ (10M NaOH concentration) to $32.54 \mathrm{~N} / \mathrm{mm}^{2}$ $(12 \mathrm{M} \mathrm{NaOH}$ concentration). Further, the increase in $\mathrm{NaOH}$ 
concentration, increases the 3-day compressive strength of geopolymer concrete by $13.05 \%$ from $32.54 \mathrm{~N} / \mathrm{mm}^{2}(12 \mathrm{M}$ $\mathrm{NaOH}$ concentration) to $36.81 \mathrm{~N} / \mathrm{mm}^{2} \quad(14 \mathrm{M} \quad \mathrm{NaOH}$ concentration). A similar trend of increase in 3-day compressive strength is seen for geopolymer concrete using copper slag as replacement to fine aggregate. This may be attributed to the fact that rise in alkali concentration boosted the geopolymerization process thereby resulting in an increased compressive strength. Further, it can be seen from Figure 2 (a) that the 3-day compressive strength of geopolymer concrete having $14 \mathrm{M} \mathrm{NaOH}$ concentration increases marginally from $29.45 \mathrm{~N} / \mathrm{mm}^{2}$ (for mix M11 with fly ash as the prime source material cured at $60^{\circ} \mathrm{C}$ ) to $29.89 \mathrm{~N} / \mathrm{mm}^{2}$ (for mix M12 with 5\% UFGGBFS as replacement of fly ash cured at ambient temperature). Strength improvement of fly ash based geopolymer concrete cured in oven at high temperatures may be attributed to the fact that curing temperatures play a vital role in accelerating the reaction mechanism [32, 33].

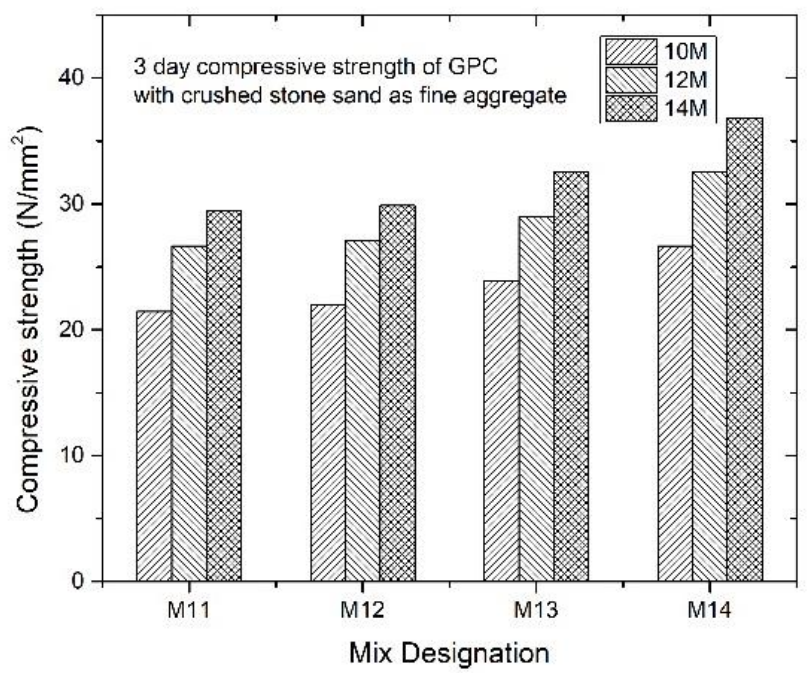

(a)

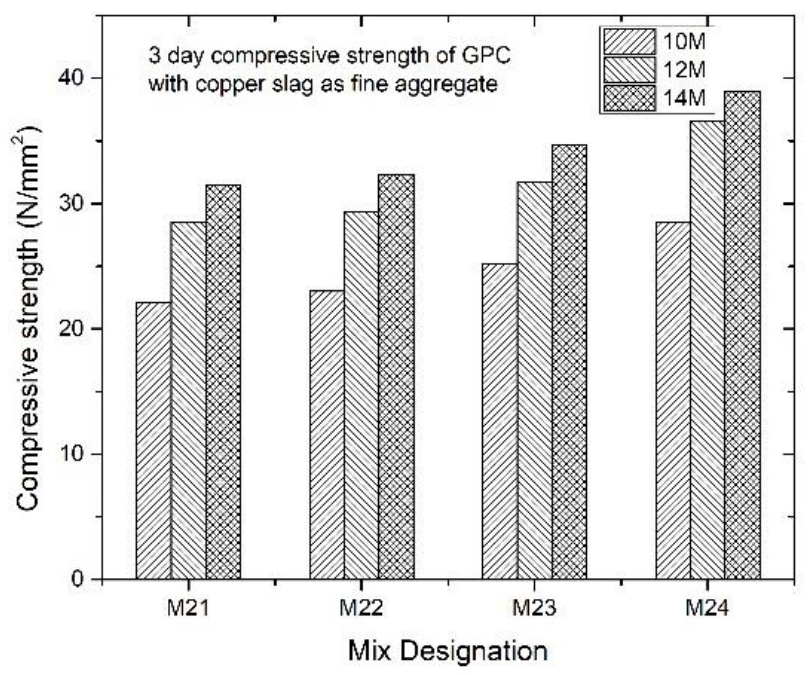

(b)

Figure 2. 3-day compressive strength of geopolymer concrete using (a) crushed stone sand as fine aggregate (b) copper slag as fine aggregate

Also, it can be remarked from Figure 2 (a) that the 3-day compressive strength of geopolymer concrete cured at ambient temperature increases with increase in UFGGBFS as limited replacement of fly ash. For instance, it can be understood from
Figure 2 (a) that the 3-day compressive strength of geopolymer concrete with crushed stone sand as fine aggregate and having $12 \mathrm{M} \mathrm{NaOH}$ concentration increases by $6.71 \%$ from 27.13 $\mathrm{N} / \mathrm{mm}^{2}$ (mix M12 having 5\% UFGGBFS) to $28.95 \mathrm{~N} / \mathrm{mm}^{2}$ (mix M13 having 10\% UFGGBFS). Further increase in UFGGBFS content from $10 \%$ to $15 \%$ resulted in an increased compressive strength by $12.40 \%$. A similar trend of increased results has been seen for geopolymer concrete using copper slag as a replacement to fine aggregate. This increasing trend may be due to the presence of $\mathrm{CaO}$ in UFGGBFS that aids in ambient curing of geopolymer concrete but also enhances the initial strength gain. It can be noted from Figure 2 (b) that the compressive strength of geopolymer concrete increases with copper slag as fine aggregate as compared to that of the geopolymer concrete manufactured using crushed stone sand as fine aggregate. For instance, it can be inferred from Figure 2(a) and Figure 2 (b) that the 3-day compressive strength of geopolymer concrete mix having 15\% UFGGBFS and 12M $\mathrm{NaOH}$ concentration increases from $32.54 \mathrm{~N} / \mathrm{mm}^{2}$ for geopolymer concrete with crushed stone sand as fine aggregate to $36.56 \mathrm{~N} / \mathrm{mm}^{2}$ for geopolymer concrete with copper slag as fine aggregate. This may be due to the amorphous nature of copper slag that aids in geopolymerization process [34].

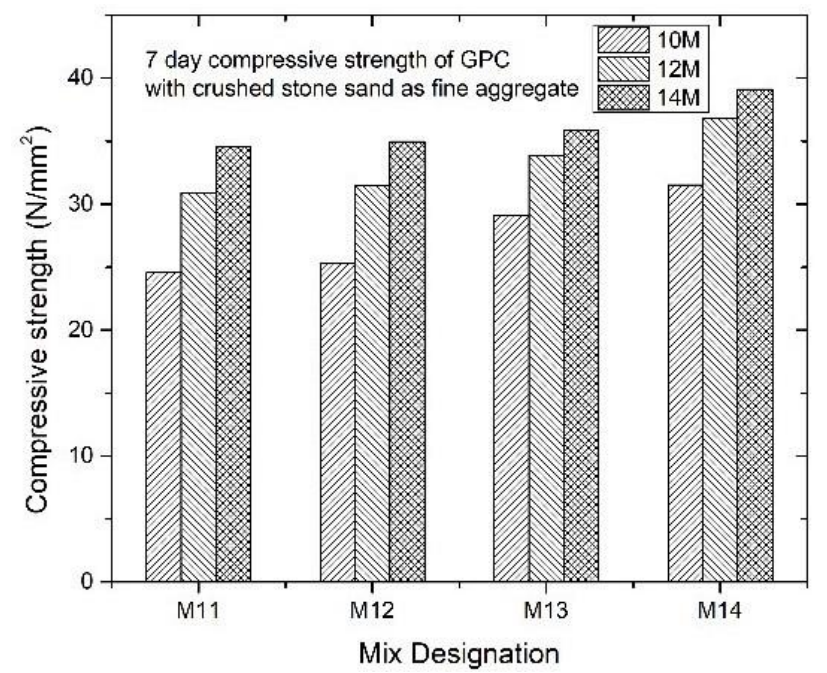

(a)

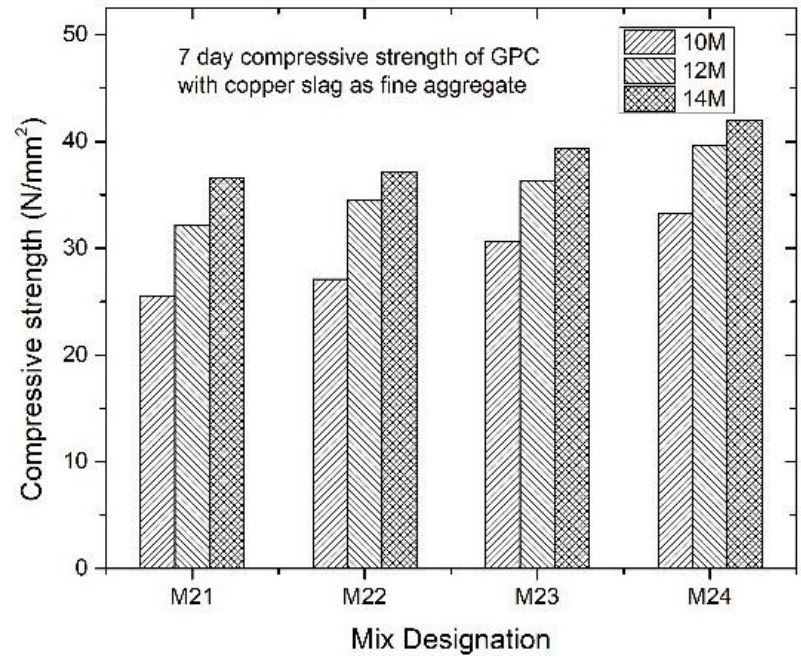

(b)

Figure 3. 7-day compressive strength of geopolymer concrete using (a) crushed stone sand as fine aggregate (b) copper slag as fine aggregate 
Figure 3 (a) shows the 7-day compressive strength of geopolymer concrete with crushed stone sand as fine aggregate and Figure 3 (b) shows the 7-day compressive strength of geopolymer concrete with copper slag as fine aggregate. From Figure 3 (a) and Figure 3 (b), it is to be noted that the 7-day compressive strength of geopolymer concrete increases with increase in $\mathrm{NaOH}$ concentration. Further, it can be noted from Figure 3 (a) and Figure 3 (b) that addition of UFGGBFS to the mix increased the compressive strength. Also, it can be seen from Figure 3 (b) that addition of copper slag as replacement to fine aggregate resulted in an increased compressive strength of geopolymer concrete as compared to that of crushed stone sand. Maximum 7-day compressive strength of $39.13 \mathrm{~N} / \mathrm{mm}^{2}$ and $41.97 \mathrm{~N} / \mathrm{mm}^{2}$ were yielded for geopolymer concrete mix with 15\% UFGGBFS content having $14 \mathrm{M} \mathrm{NaOH}$ concentration both without and with replacement of crushed stone sand by copper slag, respectively.

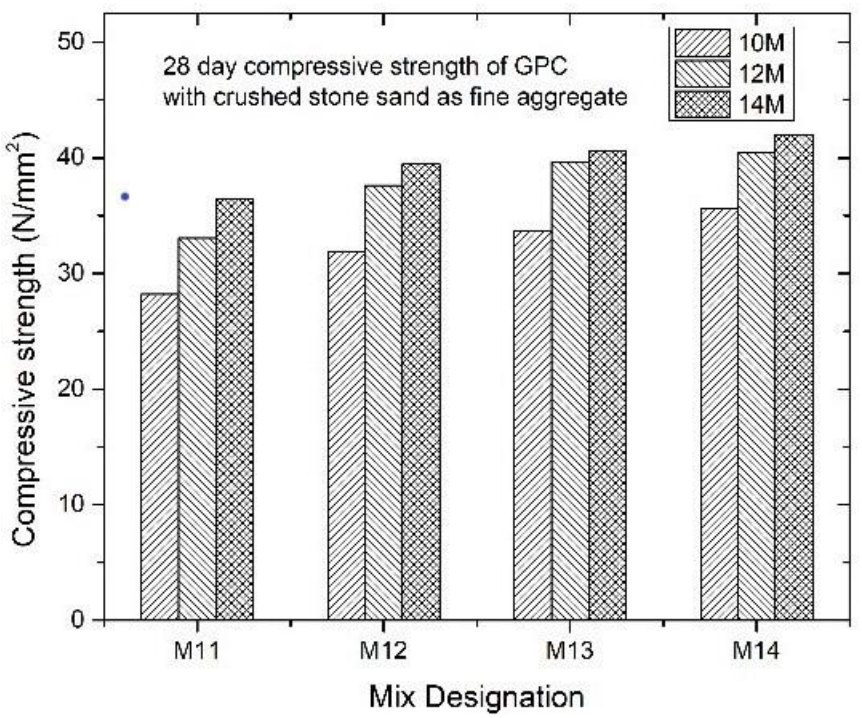

(a)

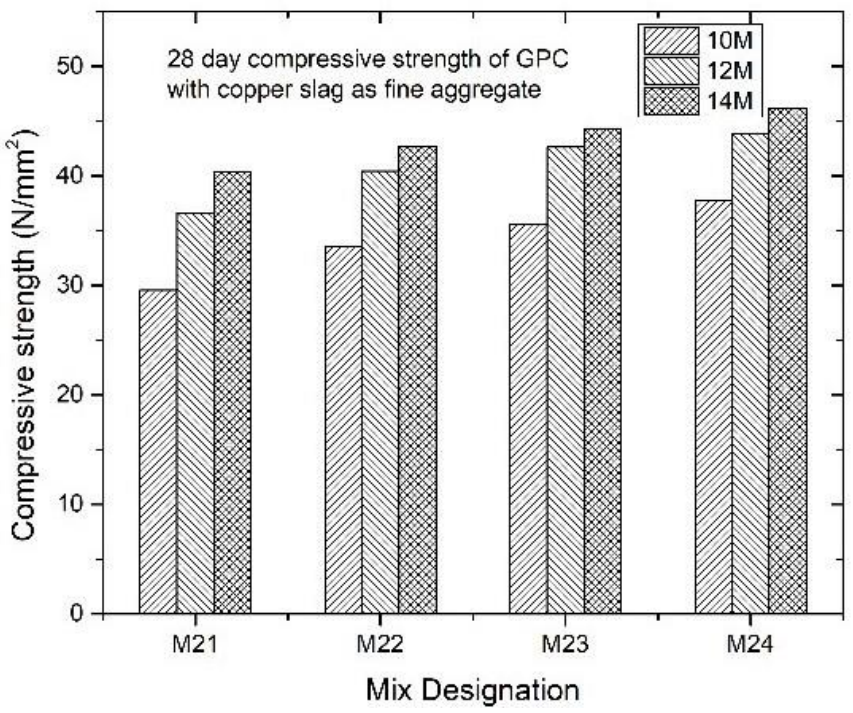

(b)

Figure 4. 28-day compressive strength of geopolymer concrete using (a) crushed stone sand as fine aggregate (b) copper slag as fine aggregate

Figure 4 (a) displays the 28-day compressive strength of geopolymer concrete with crushed stone sand being used as fine aggregate and Figure 4 (b) shows the 28-day compressive strength of geopolymer concrete with copper slag used as fine aggregate. Also, it is clear that geopolymer concrete follows the similar trend of an increase in compressive strength with an increase in $\mathrm{NaOH}$ concentration as well as increase in UFGGBFS content. It can further be highlighted that adding copper slag resulted in an enhanced compressive strength of geopolymer concrete, irrespective of the $\mathrm{NaOH}$ concentration or UFGGBFS content. Maximum 28-day compressive strength of $42.00 \mathrm{~N} / \mathrm{mm}^{2}$ and $46.15 \mathrm{~N} / \mathrm{mm}^{2}$ were yielded for geopolymer concrete mix with $15 \%$ UFGGBFS content having $14 \mathrm{M} \mathrm{NaOH}$ concentration both without and with replacement of crushed stone sand by copper slag, respectively.

\section{SEM ANALYSIS}

Geopolymer concrete mix M14 and M24 with $15 \%$ UFGGBFS content having $14 \mathrm{M} \mathrm{NaOH}$ concentration was chosen for Scanning Electron Microscopy analysis. Figure 5 (a) illustrates the SEM image of geopolymer concrete with crushed stone sand as fine aggregate and Figure 5 (b) depicts the SEM image of geopolymer concrete with copper slag as fine aggregate.

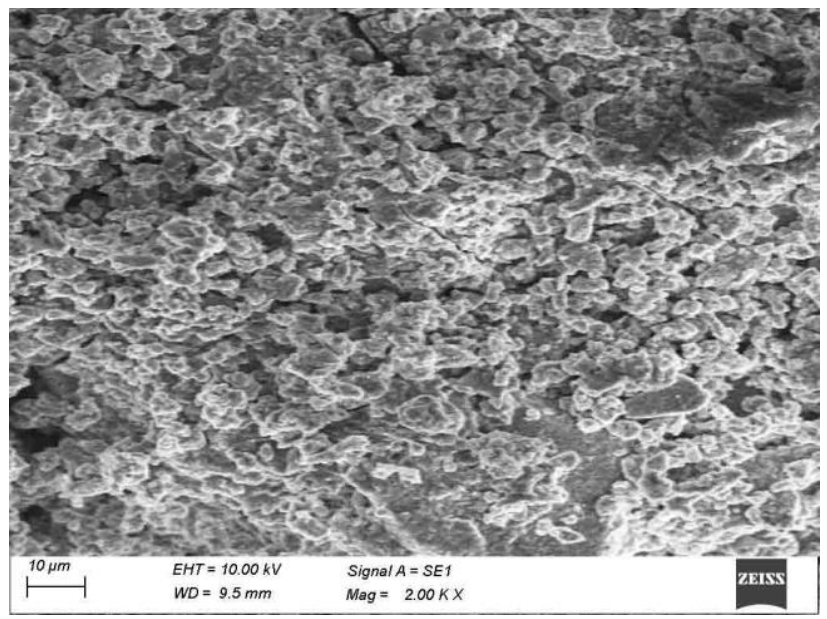

(a)

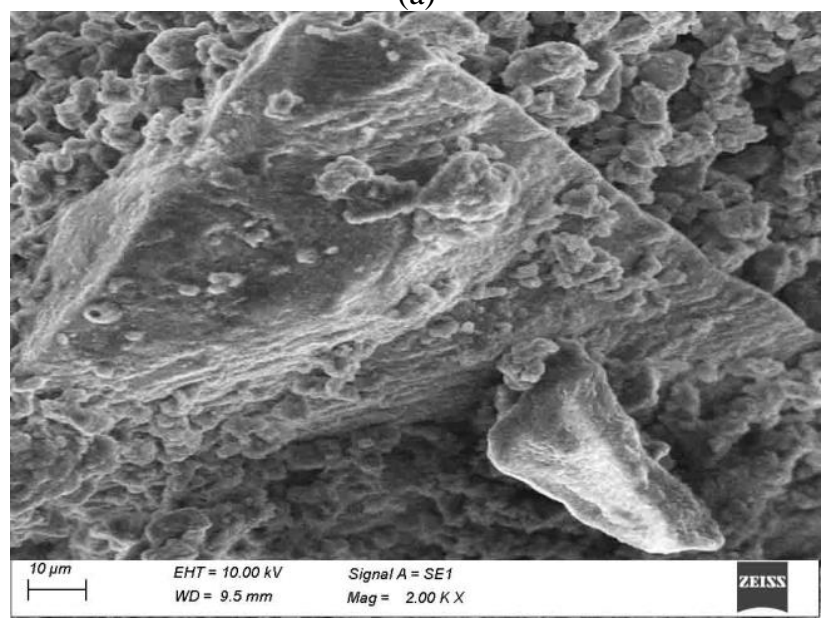

(b)

Figure 5. Microstructure of geopolymer concrete using (a) crushed stone sand as fine aggregate (b) copper slag as fine aggregate

It can be seen from Figure 5 (a) and Figure 5 (b) that adding UFGGBFS to geopolymer concrete as a replacement to fly ash resulted in an enhanced and dense microstructure. This may be due to the presence of $\mathrm{CaO}$ in the mix resulting in heat 
generation that in turn helps the fly ash particles experience geopolymerization $[35,36]$. Also, it must be seen from Figure 5 (b) that adding copper slag suggestively improves the microstructure of geopolymer concrete and the formed geopolymeric gel reduces cracks and voids, and also fills the space between aggregates [21].

Overall, it is clear from the experimental study that the strength of geopolymer concrete increases with addition of UFGGBFS as replacement to fly ash. Maximum strength was yielded for the geopolymer concrete mix with 15\% UFGGBFS content. Addition of UFGGBFS resulted in a dense microstructure that may be due to the presence of $\mathrm{CaO}$ resulting in effective geopolymerization. Further, addition of copper slag to the mix results in reduced cracks in the mix. Also, it is evident that the strength of geopolymer concrete increased with the increase in $\mathrm{NaOH}$ concentration.

\section{CONCLUSIONS}

Based on the experimental studies on geopolymer concrete using UFGGBFS as replacement of fly ash and copper slag as fine aggregate instead of crushed stone sand, the following conclusions are drawn:

- Addition of UFGGBFS enables ambient curing of geopolymer concrete.

- $14 \mathrm{M} \mathrm{NaOH}$ concentration yields the maximum compressive strength for geopolymer concrete.

- Increase in UFGGBFS content by 5\%,10\% and $15 \%$ results in an increased compressive strength of geopolymer concrete at 3, 7 and 28 days of curing.

- Replacement of crushed stone sand by using copper slag as fine aggregate resulted in an enhanced compressive strength.

- Geopolymer concrete manufactured with UFGGBFS as replacement and copper slag as fine aggregate resulted in an enhanced and dense microstructure.

- Overall, geopolymer concrete made with UFGGBFS as replacement to fly ash and copper slag as replacement to crushed stone sand can be used in cast-in-situ applications and for the manufacture of retaining walls, pavements, railway sleepers, etc.

\section{REFRENCES}

[1] Jindal, B.B., Singhal, D., Sharma, S.K., Ashish, D.K., Jangra, P. (2017). Improving compressive strength of low calcium fly ash geopolymer concrete with alccofine. Advances in Concrete Construction, 5(1): 17-29. https://doi.org/10.12989/acc.2017.5.1.17

[2] Jindal, B.B., Singhal, D., Sharma, S., Jangra, P. (2017). Suitability of ambient-cured alccofine added lowcalcium fly ash-based geopolymer concrete. Indian Journal of Science and Technology, 10(12): 1-10. https://doi.org/10.17485/ijst/2017/v10i12/110428

[3] Turner, L.K., Collins, F.G. (2013). Carbon dioxide equivalent $\left(\mathrm{CO}_{2}-\mathrm{E}\right)$ emissions: A comparison between geopolymer and OPC cement concrete. Construction and Building Materials, 43: 125-130. https://doi.org/10.1016/j.conbuildmat.2013.01.023

[4] Bisarya, A., Chouhan, R.K., Mudgal, M., Amritphale, S. (2015). Fly ash based geopolymer concrete a new technology towards the greener environment: A review.
Int. J. Innovative Res. Sci. Eng. Technol, 4(12): 1217812186.

[5] Rangan, B.V. (2008). Fly Ash-Based Geopolymer Concrete. Curtin University of Technology, Perth, Australia.

[6] Supraja, V., Kanta Rao, M. (2011). Experimental study on geopolymer concrete incorporating GGBS. International Journal of Electronics, Communication \& Soft Computing Science and Engineering, 2(2): 11-15.

[7] Detphan, S., Chindaprasirt, P. (2009). Preparation of fly ash and rice husk ash geopolymer. International Journal of Minerals, Metallurgy and Materials, 16(6): 720-726.

[8] He, J., Jie, Y., Zhang, J., Yu, Y., Zhang, G. (2013). Synthesis and characterization of red mud and rice husk ash-based geopolymer composites. Cement and Concrete Composites, 37:

108-118. https://doi.org/10.1016/j.cemconcomp.2012.11.010

[9] Ekaputri, J.J., Junaedi, S., Wijaya. (2017). Effect of curing temperature and fiber on metakaolin-based geopolymer. Procedia Engineering, 171: 572-583. https://doi.org/10.1016/j.proeng.2017.01.376

[10] Jawahar, J.G., Lavanya, D., Sashidhar, C. (2016). Performance of fly ash and GGBS based geopolymer concrete in acid environment. International Journal of Research and Scientific Innovation, 3(8): 101-104.

[11] Chithambaram, S.J., Kumar, S., Prasad, M.M. (2019). Thermo-mechanical characteristics of geopolymer mortar. Construction and Building Materials, 213: 100108. https://doi.org/10.1016/j.conbuildmat.2019.04.051

[12] Ravikumar, D., Peethamparan, S., Neithalath, N. (2010). Structure and strength of $\mathrm{NaOH}$ activated concretes containing fly ash or GGBFS as the sole binder. Cement and Concrete Composites, 32(6): 399-410. https://doi.org/10.1016/j.cemconcomp.2010.03.007

[13] Singh, G., Das, S., Ahmed, A.A., Saha, S., Karmakar, S. (2015). Study of granulated blast furnace slag as fine aggregates in concrete for sustainable infrastructure. Procedia - Social and Behavioral Sciences, 195: 22722279. https://doi.org/10.1016/j.sbspro.2015.06.316

[14] Raman, S.N., Ngo, T., Mendis, P., Mahmud, H.B. (2011). High-strength rice husk ash concrete incorporating quarry dust as a partial substitute for sand. Construction and Building Materials, 25(7): 3123-3130. https://doi.org/10.1016/j.conbuildmat.2010.12.026

[15] Chitrala, S., Ramakrishnaiah, A., Jawahar, J.G. (2015). Mechanical properties of geopolymer concrete using granite slurry as sand replacement. International Journal of Advances in Engineering \& Technology, 8(2): 83-91.

[16] Chitrala, S., Jawahar, J.G., Reddy, V.S.M., Kumar, P.D. (2016). Effect of fine aggregate blending on short-term mechanical properties of geopolymer concrete. Asian Journal of Civil Engineering, 17(5): 537-550.

[17] Chitrala, S., Jadaprolu, G.J., Chundupalli, S. (2018). Study and predicting the stress-strain characteristics of geopolymer concrete under compression. Case Studies in Construction Materials, 8: 172-192. https://doi.org/10.1016/j.cscm.2018.01.010

[18] Sreenivasulu, C., Guru Jawahar, J., Sashidhar, C. (2018). Predicting compressive strength of geopolymer concrete using NDT techniques. Asian Journal of Civil Engineering, 19(4): 513-525. https://doi.org/10.1007/s42107-018-0036-1

[19] Mithun, B., Narasimhan, M. (2016). Performance of alkali activated slag concrete mixes incorporating copper 
slag as fine aggregate. Journal of Cleaner Production, 112: $837-844$ https://doi.org/10.1016/j.jclepro.2015.06.026

[20] Chithra, S., Kumar, S.S., Chinnaraju, K., Alfin Ashmita, F. (2016). A comparative study on the compressive strength prediction models for high performance concrete containing nano silica and copper slag using regression analysis and artificial neural networks. Construction and Building Materials, 114: 528-535. https://doi.org/10.1016/j.conbuildmat.2016.03.214

[21] Kandhasamy, M., Arunachelam, N. (2016). Performance of fly ash and copper slag based geopolymer concrete. Indian Journal of Science and Technology, 9(2). https://doi.org/10.17485/ijst/2016/v9i2/86359

[22] Mathew, N.S., Usha, S. (2016). Effects of copper slag as partial replacement for fine aggregate in geopolymer concrete. In Proc., International Conference on Emerging Trends in Engineering and Management, 73-77. Peshawar, Pakistan: City Univ. of Science and Information Technology.

[23] IS 3812-1 (2013). Specification for Pulverized Fuel Ash, Part 1: For Use as Pozzolana in Cement, Cement Mortar and Concrete.

[24] IS 383-1970 (Reaffirmed 2002). Specification for Coarse and Fine Aggregate from Natural Sources for Concrete.

[25] IS: 2386 (1963). Indian Standard Methods of Test For aggregates Concrete - Part I Particle Size and Shape. Bureau of Indian Standards. New Delhi, India.

[26] IS: 9103 (1999). Indian Standard Concrete Admixtures Specification. Bureau of Indian Standards. New Delhi, India.

[27] Hardjito, D. (2005). Studies on Fly Ash based Geopolymer Mortar. Curtin University of Technology, November 2005

[28] IS: 1199 (1959). Indian Standard Methods of Sampling and Analysis of Concrete. Bureau of Indian Standards. New Delhi, India.

[29] IS: 516-1959 (Reaffirmed 1999). Methods of Tests for Strength of Concrete. New Delhi, India: Bureau of Indian
Standards.

[30] Narender Reddy, A., Meena, T. (2018). A study on compressive behavior of ternary blended concrete incorporating Alccofine. Materials Today: Proceedings, 5(5): 11356-11363. https://doi.org/10.1016/j.matpr.2018.02.102

[31] Madheswaran, C.K., Ambily, P.S., Dattatreya, J.K., Rajamane, N.P. (2014). Undefined. Journal of the Institution of Engineers (India): Series A, 95(3): 169-177. https://doi.org/10.1007/s40030-014-0084-9

[32] Davidovits, J. (1999). Chemistry of Geopolymeric Systems Terminology. Proceedings of Geopolymer. International Conference, France, 1999.

[33] Davidovits, J. (1994). Properties of Geopolymer Cements. In: First International Conference on Alkaline Cements and Concretes, Scientific Research Institute on Binders and Materials, Kiev State Technical University, Kiev, Ukraine, pp. 131-149.

[34] Singh, J., Singh, S. (2019). Development of alkaliactivated cementitious material using copper slag. Construction and Building Materials, 211: 73-79. https://doi.org/10.1016/j.conbuildmat.2019.03.233

[35] Jangra, P., Singhal, D., Junaid, M.T., Jindal, B.B., Mehta, A. (2018). Mechanical and microstructural properties of fly ash based geopolymer concrete incorporating alccofine at ambient curing. Construction and Building Materials, 180 :

298-307. https://doi.org/10.1016/j.conbuildmat.2018.05.286

[36] Gunasekara, C. (2016). Influence of properties of fly ash from different sources on the mix design and performance of geopolymer concrete. Melbourne, Australia: RMIT Univ.

\section{NOMENCLATURE}

GPC

$\mathrm{M}$

SEM
Geopolymer Concrete

Molarity

Scanning Electron Microscope 